\title{
Politický testament alebo Obzretie sa za končiacou sezónou (rozhovor s Maňom Hubom po štyroch rokoch $v$ top politike)
}

\section{Mukuláš Huba}

Envigogika 11 (1) - Dopisy a názory/ Letters and Opinion

Published/ Publikováno 1. 2. 2016

DOI: $\underline{10.14712 / 18023061.520}$

\begin{abstract}
Abstrakt
Název článku věrně vystihuje jeho podstatu - jde o bilancování práve ukončené politické kariéry jeho autora, poslance slovenského parlamentu a dvojnásobného předsedy environmentálního výboru. Dozvíme se, jak proběhl loňský rok 2015, a především, co se $v$ něm dělo za parlamentními zdmi. Text je tak vhledem do způsobu vládnutí (nejen) na Slovensku (a nejen) v uplynulém období - ukazuje, jak rozumné prístupy a řešení vždy podléhají politickému kalkulu. Nejpoctivěji vyznívá osobní krédo Mikuláše Huby, které by se dalo shrnout jako: Pracovat a nebát se, stát si za svým.
\end{abstract}

\section{Klíčová slova}

Slovensko; parlament; volební období; politické klima

\begin{abstract}
The title of this article precisely captures its essence - it is a review of the political career of its author, member of the Slovak Parliament and twice-chairman of the environmental committee. We learn about last year's events, and especially what was happening inside the walls of the Parliament. The text is also an insight into governance (not exclusively) in the Slovak Republic (and not only) in the recent period - it shows how reasonable approaches and solutions are always subject to political calculus. The honest-sounding personal credo of Mikuláš Huba can be summarized as: To work and not be afraid, to stand up for yourself.
\end{abstract}

\section{Key Words}

Slovakia; Parliament; election period; the political climate 


\section{Čím bol vlaňajšok iný?}

Najmä utečeneckou krízou, ktorá dol'ahla (aj ked' len nepriamo) už aj na Slovensko. Nárastom brutality vo svete a stále otvorenejšími prejavmi intolerancie u nás i okolo nás. Historickou skúškou solidarity a súdržnosti v rámci EÚ, ale aj eróziou demokratických princípov fungovania Slovenska a d’alších krajín regiónu V-4. Hanbou, ktorú si Slovensko, zásluhou cynického postoja niektorých svojich predstavitelov k utečencom, urobilo v Európe a vo svete.

Pápežskou encyklikou, venovanou životnému prostrediu ako priorite priorít.

Ale aj klimatickým summitom v Paríži.

\section{V čom bol vlaňajšok iný pre Teba?}

Aj $v$ tom, že okrem problémov, ktorými sa tradične zvyknem zaoberat', som bol nútený reagovat' aj na tie, ktoré súvisia s predchádzajúcou otázkou. A celkom osobne: trpel som stále väčšou únavou a znechutením $z$ diania $v$ parlamente i $v$ celej spoločnosti. Nikdy to $v$ top politike - pre ako-tak normálneho človeka - nie je príjemné, ale ked'sa zvolebnieva, tak to platí dvojnásobne.

Dotklo sa ma, že navždy z tohto sveta odišlo príliš vel'a ludí, ktorí mi boli blízki. Spomeniem aspoň mená ako Maroš Porubjak, Kornel Földváry, Ludvík Vaculík, Ladislav Chudík, Juraj Kušnierik, Ivan Štúr a v čase, ked' robíme tento rozhovor, aj páter Anton Srholec, ochranár Ivan Ondrášek a mamin brat, známy heraldik Zdenko Alexy. A dotkli sa ma aj tragické následky zemetrasenia $v$ Nepále, $v$ krajine, ktorú mám rád, či tragédia obetí vojen a teroristických útokov, ako aj tisícok utečencov, ktorí sa utopili $v$ Stredozemnom mori.

\section{Meratel'né úspechy?}

$\mathrm{Na}$ jar vedenie Národnej rady prijalo môj návrh, aby sme poskytli rekreačné zariadenie $\vee$ Častej-Papierničke na ozdravné pobyty pre deti z tých častí Ukrajiny, ktoré sú postihnuté vojnovým konfliktom.

Za druhý úspech považujem to, že sme napokon neprijali nový stavebný zákon, ktorý slúuboval viac zásadných zhoršení ako zlepšení súčasného stavu v tejto oblasti.

Celý minulý rok som sa aktívne zúčastňoval na diskusiách okolo klimatického summitu COP 21 v Pariži.

A ešte pár vecí: v praxi sa podarilo vyriešit' (neviem či natrvalo, alebo dočasne) niektoré problémy. Vznikla Výzva k l'udskosti, na ktorej som sa tak trochu podielal. Inicioval som vznik Slovenského ochranárskeho snemu. Vrátil som sa ako autor na stránky mienkotvorných printových médií. Prepadol som "zbesilej” facebookovej komunikácii s mojimi cca 3000 fb priatel'mi a priatelkami.

\section{Meratel'né neúspechy?}

Takmer všetko ostatné, resp. všetko, kde bola potrebná parlamentná väčšina (na ktorú nemáme, ako je známe, štatisticky), alebo kompromisná dohoda s vládou, na ktorú obom stranám pomyselnej barikády chýbala „politická vôl'a". 


\section{A čo tie nemeratel'né výsledky?}

Myslím si, že väčší či menší význam malo všetko, čo sme robili: od zákonov a pozmeňovákov, cez vystúpenia v rozprave, interpelácie až po organizovanie rôznych bohumilých podujatí, kde som postupoval v duchu známej pretekárskej metódy: bež stále naplno a v závere pridaj! A tak som ich len v jeseni 2015 organizoval či spoluorganizoval na pôde parlamentu sedem!

Ked' som si čítal volebné programy politických strán pred parlamentnými volbami 2016, našiel som v nich celý rad vecí, ktoré sme (spolu s pár kolegami) otvárali v Národnej rade ako jediní. Možno preto oprávnene predpokladat', že nebyt nás, tak by $v$ tých volebných programoch tie veci neboli.

Ale naozaj nemeratel'né sú len tie veci, ktoré len viac či menej oprávnene predpokladáme. A to je napríklad fakt, že už len naša prítomnost' $v$ parlamente a to, že sme niektoré záležitosti dôsledne a nekompromisne odhal'ovali a komentovali, zabránila tomu, aby sa nestali ešte väčšie hlúposti a prešlapy. Niekedy zasa naše iniciatívy a vystúpenia výrazne ovplyvnili charakter tej-ktorej diskusie. Dokonca aj zamietnutie vášho návrhu druhou stranou má svoju nezanedbatel'nú vypovedaciu hodnotu... A všetko to, čo tam z našej strany odznelo, registrovali aj prítomné médiá, zástupcovia ministerstiev a d'alší hostia. Nakolko to „padlo či nepadlo na úrodnú pôdu", je už druhá vec.

\section{A za celé štvorročné volebné obdobie, ktoré sa pomaly končí?}

\section{Najskôr: čo Ťa nepríjemne prekvapilo?}

Išiel som do parlamentu bez akýchkol'vek ilúzií, a tak ma zaskočili vari len excesy typu Štefan Kuffa, bol'ševické metódy vo vedení parlamentu a $v$ jeho útrpnom podriadení vláde, nedodržiavanie zákonov priamo na pôde zákonodarného zboru, ako aj niektoré pokútne vládno-opozičné politické obchody.

Taktiež som si celý čas nevedel zvyknút na to, že čierne sa automaticky vydáva za biele a biele za čierne len preto, lebo to pochádza z protil'ahlého politického tábora. Myslím si, že to nie je správanie hodné dospelých luduí, ktorí sú navyše platení za to, že majú viest' a spravovat' túto krajinu.

Iritovalo a demotivovalo ma aj to, že desiatky ba stovky zásadných vystúpení na dôležité témy ( $v$ mojom prípade to boli napríklad interpelácie) zostali úplne bez povšimnutia. Stávalo sa aj to, že médiá ignorovali naše upozornenia napr. počas prvého čítania k niektorému zákonu, ked' ešte bolo možné spoločnými silami vytvorit' tlak na jeho zmenu či stiahnutie z rokovania a ozvali sa nám až niekolko mesiacov po definitívnom schválení zákona, ked' tento už začal prinášat́ svoje neblahé následky, na ktoré sme včas - ale márne - upozorňovali. Za všetky takéto prípady spomeniem aspoň novelu zákona o ochrane prírody a krajiny, novelu zákona o lesoch či novelu zákona o pozemkových spoločenstvách.

A dost' som sa trápil aj na poste predsedu výboru pre pôdohospodárstvo a životné prostredie. Jednak pôdohospodárstvo nie je vel'mi moja parketa, ale aj preto, lebo byt́ opozičným predsedom výboru, ked' máte proti sebe vládnu väčšinu, ktorá apriori nesúhlasí takmer s ničím, čo poviete a navrhnete, je dost' zúfalé. Po odchode z klubu OĹaNO som túto pozíciu $v$ zmysle nepísaných politických pravidiel hry musel opustit' a s potešením som ju vymenil za vedenie mne ovel'a bližšej odbornej komisie pre ochranu prírody a krajiny pri našom výbore, s ktorou sa mi spolupracovalo podstatne lepšie než $s$ väčšinou členov

a členiek samotného výboru. 
Z hladiska kariérneho či prestižneho som vlastne stále viac a viac klesal, ale stále viac mi tento formálny „úpadok" aj vnútorne vyhovoval. Začal som ako jeden z horúcich kandidátov či nominantov na podpredsedu parlamentu (čo som však rázne odmietol), potom som dva a štvrt́ roka strávil vo funkcii predsedu dôležitého parlamentného výboru (hlasovalo za mňa 126 prítomných a len 9 bolo proti, čím sa nemôže pochválit' nikto z opozície a pribliźilo sa to k mojim rekordným "takmer havlovským" 143 hlasom v roku 1990), dva razy som sa slušne umiestnil $\vee$ prieskumoch ako potenciálny kandidát na post prezidenta (5. a 6. miesto), $\vee$ akejsi ankete som skončil $\vee$ prvej desiatke najsympatickejších poslancov (použité kritériá však nepoznám) a napokon som dopadol tak, že fungujem už rok a pol ako radový poslanec a predseda jedného z poradných orgánov nášho výboru.

A tak asi najväčší politický úspech som dosiahol hned' v prvom roku, 7. novembra 2012, ked’ po dvoch týždňoch náročných rokovaní "naprieč politickým spektrom" Národná rada takmer jednomysel'ne prijala uznesenie č. 333, v ktorom vzdáva hold autorom a autorkám Bratislavy/nahlas.

\section{Čo Ťa prekvapilo príjemne?}

Objavil som tam niekolko pozitívnych, príjemných a hodnotných l'udí. Či už medzi poslancami a poslankyňami, alebo $v$ legislatívnom a asistentskom tíme i v servisných štruktúrach parlamentu. Ked’ pre nič iné, tak kvôli týmto obohacujúcim stretnutiam a spolupráci sa tam tie štyri roky vari predsa len oplatilo strávit'. Okrem svojich poslaneckých kolegov a asistentov si dovolím spomenút aspoň pár mien: Táňa Kratochvílová, Milan Vetrák, Simona Račková, Katarína Kubišová, Martina Bagarová a Inka Vanerková. Výborne sa mi spolupracovalo aj s Parlamentným inštitútom a s l'ud'mi, ktorí mali na starosti parlamentnú kinosálu, knižnicu a iné servisné zložky, a celkom dobre som vychádzal aj s oboma tajomníkmi, ktorí sa počas "mojej éry" vystriedali pri manažovaní nášho výboru. Nenahraditel'ná bola spolupráca s externými expertmi a aktivistami/aktivistkami. Bez nich by som nedokázal ani zd’aleka to, čo som dokázal.

Aby som bol ešte konkrétnejší, najmä s kolegom Jankom Mičovským sa nám podarilo zorganizovat' a uskutočnit' niekolko desiatok vel'mi užitočných a zároveň ludsky príjemných pracovných i spoločenských podujatí, na ktoré budem vždy rád spomínat.. Často išlo o aktivity mimo parlament i Bratislavu: od hriňovských lazov a Utekáča, cez opravu pamätníka Ďurka Langsfelda pri Kremnici, exkurziu a brigádu na Čiernom Balogu, "poslanecké prieskumy" $\vee$ Slatinke, na Zaježovej, vo výberkových smolníckych lesoch, v Stupave, Dol'anoch, v Mníšku nad Popradom, Banskej Bystrici, Polomke, Hrboltovej, Modre, Svätom Jure, Tatrách, Vojke či Gabčíkove, aktivity na pripomenutie slávneho štrbského rodáka, MUDr. Markušovského, októbrový výstup na Kriváň na počest́ Štúra, návšteva zariadenia pre azylantov $v$ Gabčíkove až po týždenný pobyt na Taiwane, kde som bol spoločne s d’alšími príjemnými a zábavnými lúd'mi pod vedením Eriky Jurinovej a Jofa Viskupiča.

Nedá sa nespomenút cesty po Slovensku, ktoré som absolvoval spolu s Tebou, Rišo, a s Ĺubou a na výborné zázemie, ktoré som mal po celý čas $v$ Trenčíne, kde sme spoločne zriadili a vd’aka Vám, manželom Medalovcom, aj prevádzkovali poslaneckú kanceláriu.

S nadšením si spomínam aj na také skvelé akcie, akou bolo stretnutie s predstavitel'mi tretieho sektoru v priestoroch starej SNR, alebo Deň Zeme v r. 2013, ked' sa nám podarilo dostat́ na celý deň na Hrad 850 detí z projektu Zelená škola, výstava v Galérii na Západnej terase Hradu, venovaná 90. výročiu vzniku časopisu Krásy Slovenska alebo iná, venovaná klimatickým zmenám, niekolko tlačových besied, uskutočnených spoločne $s$ aktivistami z dotknutých lokalít, komorné ekofilmy $v$ kinosále parlamentu, demon- 
štrácia pred hradnou bránou a následná tlačová konferencia na tému VN Slatinka, Zelený salón na nádvorí Pisztoriho paláca, na ktorom som sa popredných politológov a politických komentátorov pýtal, čo mám robit́ inak a lepšie, diskusia s eurokomisárom a europoslancami o petícii európskych občanov a občianok Water 4 You: mimochodom prvá svojho druhu v EÚ - pár dní po prijatí petície $v$ Európskom parlamente (EP) a Európskej komisii, zorganizovanie diskusie s francúzskou ambasádorkou pre klimatický summit v Pariži na pôde nášho parlamentu, záštita a otváranie mnohých zmysluplných podujatí, či výstava obrazov Fera Guldana Exody pred Národnou radou, spojená s tvorivou dielňou hendikepovaných detí pod záštitou Lepšieho sveta. Alebo akcie, ako boli tradičné Dni vidieka, Deň lesa a krajiny, Na bicykli do práce, alebo podujatia s názvom Spájame statočných, iniciátorom, organizátorom a dušou ktorých bol kolega Mičovský.

A napokon, prínosom pre mňa (a dúfam, že nielen pre mňa) bolo aj niekolko zahraničných ciest, ktoré som - najmä ešte ako predseda výboru - absolvoval: Dánsko, Cyprus, Írsko, Litva, Kosovo, Rakúsko, Mad’arsko, Česko či už spomínaný Taiwan. Popri tom som stihol navštívit' nádherné kanadské národné parky, Francúzsko, precestovat' Maroko, Holandsko, Nemecko, Taliansko, Estónsko, Lotyšsko a Peru, ale to nemalo s parlamentom takmer nič spoločné.

Avšak zaujímavé boli aj prijatia zahraničných hostí: napr. partnerských parlamentných výborov z Fínska, Mad'arska a Česka, alebo skupiny holandských študentov, prezidenta združenia európskych univerzít na podporu Európskeho dohovoru o krajine, zástupkyne Svetového fóra o vode, niekolkých súčasných i bývalých ministrov životného prostredia a predsedov príslušných parlamentných výborov, ambasádorky pre klimatický summit v Parízi, bývalého francúzskeho ministra životného prostredia a d’alších.

Užitočnú spoluprácu som nadviazal aj s viacerými ambasádami a medzinárodnými štruktúrami, za všetky spomeniem aspoň francúzsku, nórsku a taiwanskú, či Zastúpenie EP na Slovensku.

Ĺudsky i profesionálne ma nemálo obohatila aj spolupráca s mojím dvojčlenným "tímom": s asistentkou Ĺubkou Trubíniovou a s Tebou.

Za jeden z najväčších úspechov považujem nepretržité prevádzkovanie webstránky i facebookovej skupiny obycajniochranari, za čo patrí vd’aka najmä Tebe, Rišo. Tu som sa snažil aj každomesačne "skladat́ účty" svojim voličom v podobe akejsi "výmesačnej" správy o tom, čo som pozoruhodného robil okrem plnenia si bezprostredných povinností poslanca.

\section{Ako hodnotíš svoje štvorročné pôsobenie $\mathbf{v}$ tomto volebnom období?}

Nerád by som hodnotil sám seba. Asi by to mali urobit iní.

\section{Ale aspoň pár slov $\mathbf{k}$ meratel'ným i nemeratel'ným výsledkom!}

Ak by mi pred tri a pol rokom, ked'sa to celé rozbiehalo, niekto povedal, že od mája 2012 do decembra 2015 stihnem viac ako 500 parlamentných vystúpení, že budem podpísaný pod takmer stovkou legislatívnych iniciatív (návrhy zákonov, pozmeňujúce a doplňujúce návrhy), že adresujem členom vlády bezmála 130 interpelácií (spolu bezmála tisíc konkrétnych otázok), že podám množstvo návrhov na doplnenie programu parlamentných schôdzí, že budem spoluiniciátorom zvolania niekolkých mimoriadnych schôdzí a odvolávaní predsedu a členov vlády, že budem organizátorom či spoluorganizátorom viac ako piatich desiatok rôznych odborných, vzdelávacích a osvetových podujatí, že poskytnem desiatky rozhovorov pre médiá a aktívne sa zúčastním početných tlačových besied 
a brífingov, budem gestorovat' a úvodným vystúpením otvárat' celý rad konferencií a diskusných fór, že budem viest' jednu z najaktívnejší poradných komisií v celom parlamente a na náš spoločný web že sa nám podarí umiestnit' viac ako 1200 príspevkov, takmer určite by som mu neveril a navrhol by som mu, nech tie počty radšej vydelí desiatimi. To by bolo také ako-tak predstavitel'né (podotýkam, že väčšina mojich parlamentných kolegýň a kolegov by sa nemohla pochválit' ani desatinovými výsledkami, v niektorých prípadoch snád' ani stotinovými!!!).

O viacerým mojich "srdcových témach", ako sú napríklad ochrana prírody a krajiny, chránené územia, pralesy, tzv. mimoprodukčné funkcie lesov, pamiatková starostlivost', ochrana prírody ako verejný záujem, ochrana riek, environmentálna výchova a vzdelávanie, ombudsman/ka pre prírodu, (trvalo) udržatel'ný spôsob existencie, zelená ekonomika, infraštruktúra či verejné obstarávanie, udržatel'ná mobilita, energetické úspory, potieranie zapáchajúcich látok, staré environmentálne zátaže, GMO, dodržiavanie nedel'ného pokoja, udržatel'né pracovné príležitosti, environmentálne, rozvojové a ludskoprávne mimovládky, podpora tretieho sektora, rozvojová pomoc, charita a mnohé d'alšie, by sa bez môjho aktívneho prispenia hovorilo $v$ parlamente ovela menej, alebo vôbec. Výsledkom bolo aj to, že o krajine, jej zranitel'nosti a potrebe ochrany jej vzhladu sa $v$ tomto volebnom období na parlamentnej pôde hovorilo viac, ako za celú novodobú históriu slovenského parlamentarizmu dohromady. Jedným z konkrétnych výsledkov hodných zmienky je napríklad deväthodinová rozprava $v$ rámci prvého a druhého čítania o vládnom návrhu novely zákona o ochrane prírody a krajiny.

A ešte jeden pozitívny dôsledok mojich/našich parlamentných iniciatív som zaregistroval $v$ týchto dňoch, ked' som si čítal environmentálne časti volebných programov strán, kandidujúcich $v$ blížiacich sa volbách. Minimálne polovica tém, ktoré sa $v$ nich objavujú, sa tam dostala vd’aka tomu, že sme na niektoré problémy $v$ Národnej rade opakovane poukazovali: až natolko, že si to museli všimnút aj naši „hluchí a slepí" kolegovia.

Na druhej strane som očakával, že budeme viac riešit́ problémy "na mieste činu". Na základe mojich skúseností z prvého parlamentného pôsobenia by som bol predpokladal, že budeme ovel'a častejšie chodit' na poslanecké prieskumy. Akosi som prehliadol, že časy i rokovací poriadok sa medzičasom zmenili a právoplatný je len ten prieskum, ktorý odsúhlasí väčšina členov výboru. A väčšinu má v tomto volebnom období v každom výbore vládna strana Smer, a tá o kontrolu svojich nominantov a obchodných partnerov záujem nemá (lebo najskôr stranícke či lobistické a až potom celospoločenské záujmy, však áno!).

Napriek tomu nie som so svojím terajším pôsobením $\vee$ NR SR $\vee$ žiadnom prípade jednoznačne spokojný. To, že neprešli takmer žiadne naše opozičné návrhy, je jedna vec. Ale to je čosi ako vis major. Skôr som si od seba viac slúuboval pri celkovom ovplyvňovaní politického myslenia i verejnej mienky "do zelena". Vel'mi sme si pritom nerozumeli ani s médiami - najmä elektronickými, ktoré tieto témy zväčša bud' prehliadali, alebo ich zaujímali iba z rýdzo straníckopolitického či bulvárneho hladiska, čo nie je moja parketa. To, že len $v$ centrálne monitorovaných médiách som mal za tri a pol roka viac ako 1000 ohlasov, nie je zanedbatel'né, ale že som pre bežnú verejnost' nebol mediálne príliš výrazný a "viditel'ný", to je tiež fakt a patrí to do kategórie mojich deficitov a sklamaní zo samého seba. A stretol som sa aj s výhradou, že akademizmus a slušnost' vo vystupovaní u mňa príliš prevládajú nad emocionalitou, sugestívnostou a expresívnostou. Je pravda, že ked' som tento "blok" v sebe prekonal, zväčša som zožal "potlesk na otvorenej scéne". Aj ked” $v$ tlačenom prepise práve takéto moje vystúpenia nepôsobia práve dokonale, ale neraz skôr neučesane až kostrbato. 


\section{Nechceš sa predsa len pokúsit' aj o čosi ako kvalitatívne (seba)hodnotenie?}

Už ked' som tam išiel, a po vol'bách v marci 2012 ešte viac, mi bolo jasné, že žiadnu "dieru do sveta" zrejme neurobím. Ale zároveň mi bolo jasné, že nechcem byt́ to, čomu sa hovorí štandardný slovenský politik, teda človek, ktorý sa správa viac-menej tak, ako mu to prikáže rodná strana a sponzori, je prospechár, egoista, egocentrik a karierista. $V$ rámci možností sa snaží maximálne využit' (a zneužit') čas strávený vo funkcii či v politike v prospech svoj a svojho "klanu", prípadne sa maximálne ulievat' a venovat' sa hlavne mimoparlamentnej práci a kšeftom. Nič z toho ma nelákalo. Méty som si staval sám a bol som sám sebe náročným šéfom. Zároveň som sa snažil urobit' čo najviac pre l'udí a prostredie, v ktorom žijú (možno to znie až pateticky, ale tak som to vnímal). Snažil som sa nikoho apriori neodmietnut́ a nezavriet́ mu dvere pred nosom. A ešte jednu neskromnú ambíciu som mal: pokúsit sa vytvorit́ model nezávisle, kompetentne, transparentne, aktívne a zmysluplne fungujúceho verejného činitel'a. Zblízka som zažil také vzory environmentálnych politikov, akými boli Josef Vavroušek, Bedřich Moldan, Ivan Dejmal, Ladislav Miko a Pavel Šremer, takže som z vlastnej skúsenosti aspoň približne vedel, ako by to mohlo a malo vyzerat́.

Bol to celé z mojej strany tak trochu experiment so sebou samým, ktorý mi zobral vela síl, ale ako hovorím vyššie, nebol to stratený čas a ruky i svedomie mi zostali čisté. Len mi tá moja rola a tie moje snahy a apely neraz pripomínali "hlas volajúceho na púšti".

Ešte na začiatku môjho prvého volebného obdobia, teda v r. 1990, nás učili, že parlament plní okrem zákonodarnej aj kontrolnú a iniciačnú či koncepčnú funkciu. Kým tú prvú som plnil "len" vysoko nadštandardne, v tých d'alších som patril jednoznačne k lídrom. Kto o tom pochybuje, môže sa presvedčit' na stránkach www.nrsr.sk a www.obycajnichranari.sk (pozn.: dnes www.ochranari.sk/archiv). A ešte $v$ troch veciach som sa priam programovo snažil odlísit' od zabehanej predstavy o slovenskom politikovi: chcel som byt́ nezávislý, robit veci naozaj, a nie len na efekt a namiesto kradnutia značnú čast' svojich príjmov rozdat́.

\section{Aj ked' poslancovanie bola Tvoja top priorita, stíhal si, pokial' viem, aj mnoho iných vecí.}

Máš pravdu. Ked' som sa stal poslancom, vzdal som sa takmer všetkých profesionálnych aktivít na akadémii, na univerzitách i v tretom sektore. Napriek tomu sa mi podarilo napísat' a vydat' šest' knižiek, pri d'alších piatich som spoluautorom a dve sú v tlači. Bol som spoluzostavovatel'om monotematického čísla časopisu Životné prostredie a urobil som niekolko profilových rozhovorov so zaujímavými osobnost́ami pre Krásy Slovenska. Viacero knižných publikácií som recenzoval. Vedeckú hodnost' PhD. získal jeden z mojich doktorandov.

V prípade dvoch mimovládok ma zvolili za čestného predsedu (čo je vôbec najlepšia funkcia, akú si viem predstavit') a s pomocou Ĺuby a Teba sa mi podarilo vybudovat' základy Slovenského ochranárskeho snemu.

$\checkmark$ lete som sa každoročne stihol venovat́ oprave dreveníc. O cestovatel'ských aktivitách hovorím na inom mieste. Relatívne $v$ zdraví som oslávil $60-\mathrm{ku}$, spolu s bratom sa staráme o našu 90-ročnú mamu a v poslednom čase sa občas venujem aj vnučke. A to je asi všetko, čo v uplynulých štyroch rokoch môjho života stojí za zmienku.

Kandidoval si v minulých vol'bách za OĹaNO - ako sa Ti spolupracovalo s týmto hnutím a s jeho jednotlivými členmi? Považuješ stále základnú myšlienku hnutia 


\section{- umožnit' nepolitikom a nestraníkom kandidovat' - za správnu a reálnu? Či s nejakými výhradami?}

My ludia sme rôzni. A v klube Ot́aNO to platilo dvojnásobne. Z tých, s ktorými sa mi tam dýchal jeden vzduch tažko, spomeniem len Štefana Kuffu. Fenomén Kuffa bol napokon aj hlavným (aj ked' nie jediným) dôvodom môjho odchodu. S väčšinou členov a členiek klubu som však nielenže dobre vychádzal, ale na stretnutia s nimi som sa vyslovene tešil: od Janka Mičovského, cez Eriku Jurinovú, Evu Horváthovú až po bývalú tajomníčku klubu, Táňu Kratochvílovú (aby som spomenul len niektorých a niektoré). Bola to pre mňa zaujímavá zmena po desat́ročiach strávených prevažne $v$ akademickom prostredí. Aj generačne išlo zväčša o l'udí o generáciu mladších, ako som ja ( $v$ prípade niektorých l'udí na sekretariáte a $v$ legislatívnom tíme bol ten rozdiel dokonca bezmála dvojgeneračný!). Rád som im ukazoval posledné pekné zákutia "mojej" Bratislavy, okolitú prírodu i vzdialené drevenice. Vláčil som ich po divadlách a výstavách, kedže vel'ká väčšina z nich je mimobratislavčanov. Som rád, že ani môj odchod z klubu nemal podobu fatálneho, nahnevaného či hysterického zabuchnutia dverí, ale komunikujeme spolu priatel'sky alebo aspoň kolegiálne dodnes.

Myšlienku dostat́ nestraníkov a nezávislé osobnosti do parlamentu považujem nad'alej za vel'mi správnu. Chyba bola, že sa celý projekt OLano rodil príliš napochytro, kandidáti sa prijímali neraz na základe nejasných kritérií, čast' (aj) kvalitných lúuí bola tesne pred vol'bami z kandidátky "odídená", ale čo je ešte dôležitejšie, takýto projekt si vyžaduje obrovskú mieru zodpovednosti, serióznosti, zrelosti a múdrosti. Ak má fungovat' klub nezávislých osobností, predpokladá to vysokú (ale nie bezbrehú) mieru vzájomnej tolerancie, preferovanie takých tém, ktoré lúdí v klube zjednocujú, a nie rozdel'ujú a vyvažovanie nezávislosti a individuality kolegialitou a kooperatívnostou. Ako vedecký pracovník s tým mám určitú životnú skúsenost'. Ved' len vd’aka takýmto schopnostiam a danostiam môžu fungovat' také vnútorne heterogénne a vysoko decentralizované samosprávne inštitúcie, ako je napríklad Slovenská akadémia vied.

\section{Z klubu OLaNO si vystúpil chvíl'u po polovici svojho pôsobenia v NR SR - ako sa Ti lepšie fungovalo: v klube či ako jednotlivcovi, nezaradenému poslancovi?}

Samému je človeku neraz otupno. $V$ klube to bolo veselšie a inšpiratívnejšie. Ale po odchode z klubu mám viac vol'ného času a menej stresov i vnútorných dilem.

\section{Často si vystupoval so svojimi/našimi environmentálnymi témami ako sám vojak v poli, takmer podl'a Aloisa Jiráska: Proti všem - tejto nevd'ačnej úlohy si sa pri- am statočne držal :) Má to ale vôbec zmysel, ak je tam so svojimi názormi člo- vek/poslanec úplne osamotený a niekedy dokonca vystavený posmechu väčšiny?}

Vlastne som len vol'ne - $v$ inom prostredí a podmienkach - pokračoval $v$ tom, čo som robil predtým. Podobne sa na zmysel dá pýtat' i v prípade vedy: kol'ko už len lúdí si vôbec prečíta Tvoj - hoci aj ten najmúdrejší - vedecký príspevok a kolkých ešte aj ovplyvní či inšpiruje? Ako pomôžeš ludstvu siahodlhým vypĺňaním rôznych tabuliek a výkazov? Dáš naozaj až tak vel'a študentom, z ktorých väčšinu aj tak nezaujíma, čo im hovoríš? Aký má význam organizovat protesty a zbierat' podpisy pod petície, ked' mocní tohto sveta si aj tak urobia, čo chcú? Aby si mi dobre rozumel, nespochybňujem dôležitost́ vyššie uvedeného, len chcem naznačit', že $s$ tým zmyslom nášho snaženia je to dost' relatívne a môžeme sa naň pýtat́ pri všetkom, čo robíme: vrátane rodenia detí do tohto neistého, riskantného a nebezpečného sveta. $V$ takomto kontexte si myslím, že tie štyri roky mali zmysel - a snád' nielen pre mňa. To, že som bol občas so svojimi názormi sám, vnímam ako realitu: tak to vyzerá $\mathrm{s}$ "našimi" témami $v$ súčasnej slovenskej politike, a žial', nielen v politike, ale $v$ celej spoločnosti (čest' výnimkám). Samozrejme, že keby tam bolo viac environmentalistov, 
zelených a vizionárov, bolo by o nás a našich prioritách viac počut'. Ale naštastie, nie vždy som bol osamotený a niekedy ma podporili dokonca aj ludia, od ktorých som to nečakal (napr. z prostredia SaS, Siete, NOVY či KDH). Čo ma však postupne deptalo a prečo sa ma zmocňovala stále viac a viac „porazenecká mentalita”, to bola skutočnost', že nech som povedal a navrhol čokolvek rozumné, napokon ma vládna väčšina prehlasovala. Ked' sa to stane raz, alebo hoci desat́krát, tak sa to ešte dá vydržat', ked' sa Ti to však stane tisíckrát (a takmer bez výnimky), začne to byt́ deprimujúce. Nikto z nás predsa nie je stroj! Apropo, prirovnal by som to $k$ situácii vysokoškoláka, ktorého vždy znova a znova vyhodia zo skúšky, bez ohl'adu na to, či je na tú skúšku riadne pripravený alebo nie. Aj v tomto je ten opozičný pobyt na Vodnom vrchu nebezpečný: urobí z Teba postupne nihilistu, rezignovaného človeka a neraz aj chladného pragmatika až cynika a môže Ťa to zlomit', zbavit' vnútornej integrity, sebaúcty, ale aj pocitu zodpovednosti, ked' vieš, že na Tvojom názore a na Tvojom hlase $v$ konečnom dôsledku aj tak nezáleží. A ešte niečo: pobyt $v$ top politike nie je ani tak intelektuálne náročný, ako skôr emocionálne. Niekedy som sa odmietol angažovat́ $\checkmark$ nových veciach ani nie tak pre nedostatok času či kompetencie, ale jednoducho preto, lebo som sa obával, že nový konflikt emocionálne nezvládnem. Aj preto si myslím, že každý ústavný činitel' by potreboval svojho vlastného psychiatra.

Na druhej strane, byt členom vládnej strany či koalície je síce o niečo menej zúfalé a beznádejné, ale to zasa so sebou prináša iné riziká a nástrahy.

\section{Máš s odstupom takmer štyroch rokov a skúsenostou, ktorú si absolvoval, pred- stavu, čo by sa dalo robit' inak, lepšie...?}

Nič a nikto nie sme dokonalý, a preto je logické, že všetko sa dá robit́ lepšie. Ale obávam sa, že aj keby som podal skutočne nadludský výkon a robil dvakrát viac a dvakrát lepšie, výsledok by v zásade nebol príliš odlišný. Otázka je, či sa niektoré veci nedali robit́ zásadne inak. To zásadne inak znamená robit' väčšie kompromisy a viac spolupracovat' s vládou, ministerstvami a prípadne aj s poslaneckým klubom Smer-SD. Takáto spolupráca (či skôr kolaborácia?) by mi zrejme bola priniesla zopár prijatých pozmeňujúcich a doplňujúcich návrhov, možno aj jedného či dvoch menej dôležitých návrhov zákonov. $\mathrm{Na}$ 99 \% som si však istý, že ani keby som obetoval kus svojich zásad, nebol by som nič podstatnejšie presadil a straty by prevážili nad prínosmi. Môžeš sa opýtat', čím je ten prínos, ked' sme dosiahli tak málo meratelných úspechov? Podla mňa je tým prínosom jasne vyslovený názor, konkrétne návrhy na nové či lepšie riešenia, zväčša dotiahnuté až do legislatívnej podoby, čiže niečo, ako reálna (aj ked' predbežne neprijatá) alternatíva voči vládnej politike ( $a$ to nielen vo sfére životného prostredia). $V$ tom vidím najväčší význam dôsledne realizovanej opozičnej či alternatívnej politiky: vytvorit́ zmysluplnú alternatívu, víziu, základy, na ktorých sa dá stavat' iná realita. Niečo, čo má konkrétne kontúry a jasné farby, a nie je to rozmazaná machula bezzásadového kompromisu, ktorá viac či menej legitimizuje to, proti čomu vlastne protestuješ.

\section{Ale predsa, nie je škoda, že tam už nebude poslanec Huba?}

$\checkmark$ prvom rade, ak tam takéto typy verejných činitel'ov chceme mat', je treba sa vynasnažit', aby sa tam dostali (pokial' možno o desat' či dvadsat' rokov mladší) lúdia podobného naturelu, presvedčenia či razenia. Po d'alšie, môj odchod z top politiky neznamená, že sa neplánujem $v$ budúcnosti angažovat' a vyjadrovat' sa $\mathrm{k}$ veciam verejným. A napokon, ale nie na poslednom mieste - aj v nadväznosti na vyššie povedané - možno trochu egocentricky až megalomansky, ale úprimne a realisticky: poslancov je 150, ale Maňo Huba je iba jeden, a preto by som nerád prestal byt́ sám sebou a vymenil svoju identitu za niečo síce relatívne vysoko postavené, ale vo svojej podstate úbohé a nedôveryhodné. Lebo je prav- 
da, že takmer nepoznám v našej vrcholovej politike človeka, ktorý by tam bol dlhodobo a zostal normálnym, reálne uvažujúcim, empatickým, tvorivým a sebakritickým.

Aj preto je tam dlhodobý pobyt „životu nebezpečný" nielen pre občanov, ktorých (zväčša len akože) zastupujete, ale aj pre Vás samotných. Východiskom je podla mňa rotácia kádrov spojená s využitím skúseností a poznatkov lúdí, ktorí tam nejaký ten čas aktívne, invenčne a poctivo strávili.

\section{Kde si v vlastne čerpal silu? Prečo si sa o niečo znova a znova snažil, aj ked' si už nevládal?}

Chvílami som to robil už len tak akosi zo zotrvačnosti. Inokedy preto, lebo ma oslovili priatelia, aby som s nimi do niečoho nového išiel, alebo, ked' ma požiadal niekto z externého prostredia, či by sa nedalo niečo na pôde parlamentu zorganizovat'.

Ku koncu som však už bol skutočne "na konci s dychom" a aj preto som si nevedel ani len predstavit', že by som znova kandidoval. A pritom $v$ parlamente sa dá prežit́ pohodlne aj niekolko volebných období za sebou: pokial' je človek flegmatik či lacný pragmatik a uspokojí sa s minimálnymi výkonmi, čo však nie je môj prípad. Môj problém bol aj $v$ tom, že som tam po 40 rokoch aktivizmu a plného nasadenia už začínal ako človek "unavený životom", čo sa rokmi len stupňuje.

\section{Cítil si podporu zo strany environmentalistov, zo strany environmentálnych či iných organizácii 3. sektora? Podporili Ťa v týchto snahách a (prepáč) niekedy možno až donkichotských t́aženiach nejaké známe a mienkotvorne osobnosti?}

Podporu zo strany časti environmentalistov a expertov som cítil nepretržite. Na ludí ako Mat́a Paulíková, Janko Topercer, Marika Kozová, Ĺuba Lacinová, Miro Mojžiš, Imro Vozár, Dušan Bevilaqua, Dano Lešinský, Palo Široký, Juraj Rizman, Roman Havlíček, Tomáš Derka, Jano Hanušin, Vlado Ira, Dino Hochel, Pepsi Klučka, Ĺuba Kolková, Jano Lacika, Milan Lichý, Braňo Líška, Vladino Mokráň, Tomáš Peciar, Heňo Pifko, Eva Kováčechová, Dana Mareková, Soňa Párnická, Ĺubica Krištofová, Mirka Čierna, Lydka Priehodová, Natália Šovkoplias, Drahoš Stano, Pavel Šremer, Peter Straka, Lucia Štasselová, Anka Zemanová, Ďuro Mesík, Vierka Dubačová, Klaudia Medalová, Katka Rajcová, Braňo Moňok, Juro Zamkovský, Pal'o Ziman, Dáša Lišková, Jana Pavlíková, Ela Štefanová, Ďuro Hipš, Elena Fatulová, Rudo Pado, Nad’a Škodová, Janko Szöllös, Jožo Ridzoň, Sabína Barborjak, Boba Balúchová, Edo Stloukal, Ĺubica Hildebrandová, Marek Kurinec, Juraj Švajda, Juraj Vysoký, Erik Baláž, Pal'o Bakoš, Jozef Šibík, Mišo Deraj, Laco Bíro, Hana Fábry, Anka Dobrucká, Mat́o Vagač a niektorých d'alších sa dalo vždy spolahnút a boli mi velkou oporou.

Čo sa týka mienkotvorných osobností, permanentne som cítil nezištnú podporu zo strany skvelých umelcov a zároveň L’UDí, akými sú Fero Guldan, Zuzka Kronerová, Samo Smetana, Zuzka Homolová, Vierka Dubačová či Juraj Nvota. Povzbudivé slovo mi pri každom stretnutí nezabudol povedat́ ani Tonko Srholec, Martin a Zora Bútorovci, Miro Kocúr, Juro Kušnierik, Rudo Sikora, Miro Cipár, Ferko Mikloško, Tomáš Janovic, Ĺuba Lesná, Marta Šimečková, Maroš Porubjak, Peter Tatár, Pavol Demeš, Pišta Vandal, Ivan Štúr, Viktor Hulík, Zuzana Dolejšiová, Eugen a Zuza Gindlovci, Dano Kollár, Elena Flašková, Rišo Krivda, Ivan Štrpka, Marián Mudroch, Monika Kozelová, Tono Popovič, Adrian Rajter, manželia Minárikovci, Erik Ondreička, Marián Minarovič, Darina Abrahámová, Fedor a Egon Gálovci, Janka Michalová, Mirka Ábelová, Peter Horváth či Daniel Pastirčák (a mnohí d'alší/d’alšie). Takmer všetci ma úprimne lutovali a nevedeli pochopit', ako to tam vôbec vydržím. 


\section{Čo bolo Tvojou dennou drobnou radost'ou v parlamente? Na čo si sa tam tešil?}

Zo začiatku som sa tešil na stretnutia s niektorými l'ud'mi okolo OĹaNO. Už som spomínal, že vela pozitívneho sme vymysleli a zažili najmä s Jankom Mičovským, ale príjemné boli aj "team buildingy" na Sliači, v Ždiari, Novoti, Častej-Papierničke, v Starej Ĺubovni, Košiciach, Žiline, na Čiernom Balogu...

Tešil som sa na "nepovinné" akcie, ktoré sme organizovali popri svojich povinnostiach a ktoré spomínam na iných miestach tohto rozhovoru. Príjemné boli aj niektoré spoločenské podujatia. A celé štyri roky som pocitoval možnost' de facto s čímkolvek a kedykolvek vystúpit́ ako niečo na spôsob drogy: áno, som pri tom, kde sa niečo deje a môžem do toho $v$ súlade so svojím vedomím a svedomím zasiahnut'. Bezprostredne tým zrejme vela nezmením, ale akási stopa - minimálne kdesi v archíve - po tom zostane. Pomôžem sprístupňovat' parlament a poskytovat' jeho kapacity l'ud'om. Budem sa pozerat' na prsty mocným a pýtat́ sa ich, prečo niektoré podozrivé a zlé veci robia a iné, užitočné, nerobia, $v$ nádeji, že ich to aspoň trochu ovplyvní. A snád' sa mi podarí vytvorit́ čosi ako model zmysluplne fungujúceho verejného činitel'a. Páčilo sa mi, že je tam málo byrokracie a že sa od teba očakáva, že budeš uvažovat' o dôležitých veciach, trápiacich túto spoločnost' a najrôznejšími spôsobmi sa k nim vyjadrovat', bez toho, že by si si od niekoho musel pýtat povolenie, alebo niečo do detailu pripravovat' a donekonečna prerábat', aby to bolo po formálnej stránke akože dokonalé. Aj inštitút faktickej poznámky je dobrá škola: musíš sa naučit vtesnat svoje posolstvo do dvoch minút. Každé tvoje slovo navyše už beží mimo záznam.

Do d’alšieho volebného obdobia už nekandiduješ, čo/kam/s kým sa chystáš robit'/cestovat'? Máš pred sebou nejakú novú výzvu?

V USA a v niektorých d'alších krajinách je neodmyslitel'nou súčastou pracovného cyklu tzv. sabatical year. Rok, kedy pokial' možno úplne zmeníš zabehnutý rytmus života a robíš niečo úplne iné. Tradične to býva každý siedmy rok. Ja tento sabatical odkladám už vari od maturity, teda viac ako 40 rokov, takže je už najvyšší čas: ak to chcem stihnút ešte pred vlastným pohrebom. A po tom roku sa uvidí, čo ma osloví. Mám určité predstavy a plány, ale nechcem íst' "s bubnom na zajace".

Množstvo návrhov zákonov a noviel zákonov, ktoré si sám alebo s d’alšími kolegami poslancami - aj za účasti odborníkov či aktivistov - počas Tvojho pôsobenia v NR SR pripravil a predložil, skončilo kvôli arogancii väčšiny zo Smeru v šuflíku. Napríklad aj také dôležité a celospoločensky prospešné legislatívne vylepšenia, ako zakotvenie ochrany krajiny do ústavy, systém zálohovania obalov, väčšie zapojenie polície a občanov do potierania čiernych skládok, legislatívne posilnenie environmentálnej výchovy a vzdelávania, uzákonenie nedel'ného pokoja, legislatívne zakotvenie ochrany l'udí pred zapáchajúcimi látkami z priemyslu, systematickejší monitoring a informovanie verejnosti o kvalite ovzdušia, zabránenie konfliktu záujmov v rámci procedúry EIA/SEA, prísnejšia regulácia GMO, podpora lazníckeho osídlenia a jeho obyvatel'ov, "ozelenenie" lesného zákona i procesu verejného obstarávania, kompetenčný a organizačný prevod národných parkov pod rezort životného prostredia, posilnenie kompetencií stráže prírody, zriadenie inštitútu ombudsmana pre prírodu, nové chápanie verejného záujmu, akceptácia komplexnej hodnoty lesa, väčšia spravodlivost' pre členov pozemkových spoločenstiev, ochrana charakteristických čŕt krajiny, zrovnoprávnenie postavenia verejného ochrancu práv s ostatnými ústavnými činitel'mi, zrušenie Mečiarových amnestií, uzákonenie hmotnej zodpovednosti verejných činitel'ov za spáchané škody, posilnenie inštitútu priamej demokracie, umožnenie kandidovat' nestraní- 
kom, účinnejšie potieranie korupcie, obmedzenie inštitútu výnimiek, prvky ekologickej daňovej reformy a iné zmeny $v$ štátnom rozpočte a mnoho d'alších. Je šanca, že pri lepšej „konštelácii hviezd" v novej NR SR po vol'bách, ale pri Tvojej neprítomnosti v nej, niekto tieto legislatívne návrhy zo šuflíka vytiahne, osvojí si ich a opätovne predloží?

Myslím si, že v prípade väčšiny týchto dosial' neúspešných - ale dobre pripravených - legislatívnych návrhov táto šanca je, ak sa do parlamentu dostane aspoň čast' z tých l'udí, s ktorými som na ich príprave spolupracoval.

Tvoje hodnotenie pôsobenia v NR SR vyznieva dost' skepticky, skoro sa bojím, aby sa neodrazilo v nechuti našich priatel'ov a známych, či našich čitatel'ov íst' volit' v najbližších - marcových - vol'bách do NR SR. Čo by si odporučil voličom v týchto vol'bách? Na čo by si pri výbere strany/hnutia/zoskupenia mali dat' najviac pozor? Koho krúžkovat'? Či už konkrétne, alebo aspoň typovo?

Nechcem l'udí od volieb odhovárat'. Naopak, chcem ich povzbudit'. Aj moja skúsenost' osamelého cezpolného bežca je potvrdením toho, že ak nejde volit' vel'ká čast' slušných, kultúrnych, ekologicky cítiacich a vzdelaných voličov, potom šanca, že sa tam dostanú vhodní kandidáti (alebo ak chceš našinci), sa výrazne zmenší. A my tam takých lúuí potrebujeme. Aj keby ich bolo opät' len zopár. Lebo je obrovský rozdiel, či máš so svojím problémom v parlamente za kým zájst', alebo nie. Z môjho pohl'adu by bolo ideálne, keby bolo po týchto štyroch rokoch komu odovzdat' štafetu - hoci len na d'alšie štyri roky.

Aj ked' nič som nikomu neslúbil a nezaviazal sa ani len náznakom, že mu budem pomáhat' robit' kampaň pred volbami, musím povedat', že našincov, ktorých by som rád videl $v$ budúcej Národnej rade, kandiduje opät málo, a ak by sa tam celkom hypoteticky dostali aj všetci, budú opät vo výraznej menšine. Ale krúžkovat' by som vedel s čistým svedomím minimálne dvadsat' lúuí na rôznych kandidátkach. Ak mám byt́ ešte konkrétnejší, d'aleko najviac z nich sa opät nachádza na kandidátke Otano (hoci sú tam zároveň aj lúdia, ktorí sú pre mňa táažko prijatel'ní, ale to sa zrejme nezmení, pokial' sa bude dat́ kandidovat' iba na straníckej listine a nebude si možné vybrat' aspoň čast' svojich favoritov naprieč politickým spektrom - čo sme opakovane, žial' neúspešne, navrhovali). Liberálni voliči dokážu nájstt' "krúžkovatel'nú štvoricu" našincov aj na kandidátke SaS a ochranári a im príbuzní sa nájdu roztrúsení aj na kandidátkach d'alších opozičných strán.

\section{Aké posolstvo by si chcel zanechat' svojim nasledovníkom?}

Bolo by toho viac, ale odpoviem len tak "z prvej ruky": nevyhýbajte sa veciam verejným, vrátane aktívnej „politickej služby”. Riadte sa svojím vedomím a svedomím, ale zároveň budte kolegiálni a solidárni! Uchovajte si ideály! Vytvorte si vlastný program a víziu zmysluplného verejného činitel'a a tie sa snažte krok za krokom napíňat'! Budte zásadoví a zároveň tolerantní, nároční a kritickí voči silným a empatickí voči slabým! Nebudte príliš egocentrickí a už vôbec nie arogantní! Vážte si záujem luudí o vašu prácu!

Venujte sa každému, kto to naozaj potrebuje a nik iný mu nedokáže momentálne pomôct' lepšie, ako vy! O svoj príjem a výhody sa aspoň sčasti podelte s tými, ktorí to naozaj potrebujú a podporte zmysluplné veci, ktoré sú bez vašej pomoci ohrozené! Budte angažovaní, ale nepodliehajte stádovitosti a uchovajte si schopnost́ kritického myslenia (aj voči sebe a svojim najbližším)! Nebojte sa byt' iní, vyzerat' hoci naivne a "plávat' proti prúdu", ked' budete presvedčení o svojej pravde! Nepýtajte sa, čo za to! Zostaňte normálnymi, triezvymi, slušnými lud'mi! Zachovajte si nadhlad a zmysel pre humor!

Ak vám v tom budem vediet' akokolvek poradit', rád to urobím. 
Zhováral sa Richard Medal

Bratislava/Trenčín, február 2016 